\title{
Life Cycle Analysis of Ponggok Tourism Village, Polanharjo District, Klaten Regency, Central Java Province
}

\author{
Khusnul Bayu Aji ${ }^{*}$, Arif Kusumawanto ${ }^{2}$ \\ ${ }^{1}$ Graduated Student of Architecture Majoring in Architecture and Tourism Planning, Department of Architecture and \\ Planning, Faculty of Engineering, Universitas Gadjah Mada, Yogyakarta, Indonesia \\ ${ }^{2}$ Associate Professor at Department of Architecture and Planning, Faculty of Engineering, Universitas Gadjah Mada, \\ Yogyakarta, Indonesia
}

\begin{abstract}
This study aims at analyzing the development of Ponggok Tourism Village since its first progression as a tourism destination. Ponggok is one of the best tourism villages in Indonesia according to the 2017 report published by the Ministry of Villagers, Disadvantaged Regions and Transmigrations. However, the tourism village tends to be in a stagnant condition and even experience a decline in visitors. The life cycle analysis is chosen as the approach to fulfill the requirements needed to study the time series (longitudinal) data to dissect the development of Ponggok Tourism Village. The indicator and parameter of assessment in this life cycle analysis is the model stated by Laurenço: planning, action, and living. The technique of primary data collecting is through observation, mapping, interview, and Focus Group Discussion (FGD). Furthermore, the secondary data is acquired through literature studies and institutional surveys in accordance with the scope of the study. The result of the research shows that the development of Ponggok Tourism Village has, at least, four segments of time. The first segment occurred in 2007-2010, the second segment occurred in 2011-2013, the third segment was 2014-2016, and the fourth segment of time occurred in 2017-2018. In the aftermath of this study's results, it is recommended that Ponggok Tourism Village need to replan their strategies to avoid the stagnation-decline stage and to stimulate the occurrence of rejuvenation.
\end{abstract}

Keywords: Life Cycle Analysis, Ponggok, Tourism Village.

\section{INTRODUCTION}

Tourism is a global phenomenon and grows rapidly as one of the biggest economic sectors that can contribute to poverty alleviation in developing countries [1-3]. This opinion arises from the belief that tourism can generate foreign-exchanges, increase job opportunities, and encourage investment [4,5]. In addition to economic benefits, there is also a claim that tourism contributes to the forming social power transformatively, through the increase of individual welfare and the perspective on the importance and the needs of community empowerment $[6,7]$. In the cultural context, tourism acts as a media that can stimulate interaction and communication between individuals or groups with various cultural backgrounds [8] that finally influences the interests on cultural legacies and heritages, the appreciation of localities, and the increase of cultural infrastructure investment [9].

This global tourism development reaches Indonesia and can be seen from the growing numbers of tourist villages from 2010 up until now. In 2009, there are 144 tourist villages in

\footnotetext{
* Correspondence address:

Khusnul Bayu Aji

Email : khusnulaji1994@gmail.com

Address : Bulaksumur, Kabupaten Sleman, Daerah Istimewa Yogyakarta 55281
}

Indonesia. That number grows drastically into 987 tourist villages in 2014 and 1,734 in 2019. According to the data from the Ministry of Village, Development of Disadvantaged Regions, and Transmigration, there are 1,902 potential villages in Indonesia that can be developed into a tourist village.

Although the quantity of tourist villages keeps increasing every year, the same cannot be said in terms of quality. One of the considered successful tourist villages is Ponggok Tourism Village, Polanharjo district, Klaten regency, Central Java province. This village was just awarded as the Best Tourism Village in terms of community empowerment by the Ministry of Village, Development of Disadvantaged Regions, and Transmigration. Ponggok dubbed as successful because previously, it was the poorest village in Polanharjo district, Klaten Regency. After the rapid growth of its tourism sector, Ponggok becomes one of the richest villages with annual Original Village Revenue (PADes) that worth billion Rupiah. However, Ponggok currently faces stagnation, even a decline. It was shown by the number of visitors presented in the Figure 1.

The starting point of tourism activities in Ponggok began in its development process in 
2007, the same year the Village Master Plan ${ }^{a}$ was created. It is used as the guideline to build and develop Ponggok in many sectors, including tourism. So far, Ponggok has been through the development process for 12 years, until this middle of 2019. This length of development period is ideal and adequate to analyze, considering the claim of the stagnant or even decline phase of the Ponggok's tourism, which is based on the statistics of the tourist visit as the early indicator.

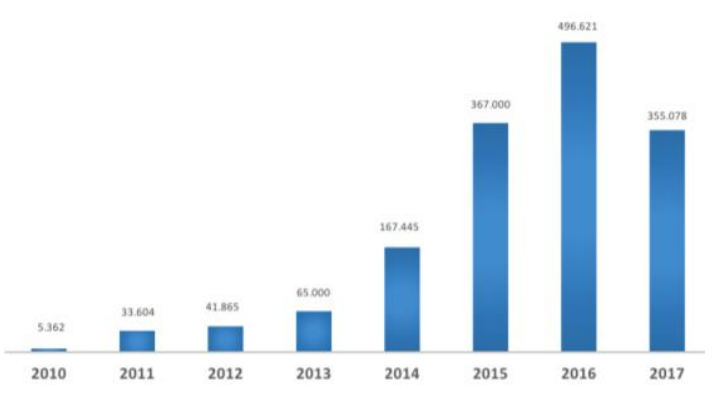

Figure 1. The Number of Visitors of Ponggok Tourism

\section{Tourism Destination}

A tourism destination can be defined as a place or location that offers tourism products and a complete experience, managed by certain parties in order to attract the tourists to visit - to engage in tourist trips and staying for a certain period [10-12]. The characteristic of a tourist destination is identical to the spatial and social entity $[13,14]$. On the spatial entity, the characteristic of a tourist destination can be associated with cultural landscape, scale, physical boundaries, and spatial hierarchy [13]. While in the social entity, the characteristic emphasizes its association with the condition of the local community that covers the economic structure, social structure, and social organization, and political institution [14].

Furthermore, as an industry, tourism should, ideally, has four components needed to attract the tourists to visit, to provide all the accommodation. It covers a) attraction; b) amenity; c) accessibility; d) ancillary services. These four components are commonly referred to as ' $4 A^{\prime}$ ' [15].

The availability of those components on a tourism destination or tourism region based on spatial perspective will create a pattern based on the characteristics or the usage that suitable for

\footnotetext{
a Also known as Rencana Pembangunan Jangka Menengah Desa (RPJMDes).
}

the physical setting of each tourism destination [16]. It also explained that a tourism area/destination can have one or many attractions. It is also called the nucleus. Then one or more Nucleus will have supporting areas which commonly used as functional land or aesthetic area called Inviolate Belt. A group of Nucleus and Inviolate Belt that receives intervention from the local community by building various facilities such as toilets, restaurants, accommodation services, or Tourist Information Center (TIC) will be called as Zone of Closure. The Nucleus and Inviolate Bels within the Zone of Closure are connected with Path. The Zone of Closure that has Nucleus and Inviolate belt can be connected on a bigger scale (in the presence of access) and will be called Circulation Corridor [16].

In addition, the making of a tourism destination from a spatial perspective is also related to tourist's activities and movement. There are two models to see the tourist's activity and movement in a certain destination or region, by the territorial and linear model [17]. As understood, the territorial model is used to find the tourist's activity intensity, while the linear model is used to find the movement direction and pattern of the tourist.

Last but not least, here is the literature review of the tourism village. The tourism village is commonly understood as a tourism destination that integrates tourism attraction, public facility, and accessibility infrastructure and is assimilated with the community's life structure and customs [18]. Chronologically, two perspectives support the basic idea of how to manage a village as a tourism destination. The first is the global tendency to choose local small-scale village accommodation, which management is inseparable with the local community, by the tourist. The second is the sustainability of community-based tourism that is managed based on spatial limits administratively.

\section{Life Cycle Analysis}

A tourism destination will surely endure changes and development from time to time. Therefore, a conceptual approach emerges to read the life cycle of a tourism destination by examining its various aspects of changes such as land usage, economy building, and the destination's marketing efforts [19]. In the 80s, Butler proposed a model of life-cycle analysis that can be applied to a tourism destination called Tourism Area Life Cycle (TALC [20]. 
More than 30 tourism regions or destination had been studied using this model (TALC). For example, Hovinen [21] applied TALC to analyze the growth of Lancaster County tourism destination in Pennsylvania; Butler [22] used the approach to analyze the development of tourism destinations in Scotland's highlands and Haywood in 1986 with a similar approach for the research. The TALC model started to be massively implemented in the '90s, with its prominent figure $[15,20]$.

Even though the TALC has been a common approach to monitor or evaluate a tourism destination's development, it still has a limitation. The linear narration of TALC cannot accurately and strictly analyze the complex interaction and power that acts as a determining factor in the creation of a tourism destination $[23,24]$. Besides, the unclear parameters of each TALC's indicator caused unmeasured justification to determine the extents and the stages of development of a tourism destination [20]. This condition affects the assessment of the tourism destination growth due to its relative measurements.

Butler, in his writings as TALC creator, even criticizes the approach himself. The life-cycle of a tourism destination cannot be seen as linear anymore [25]. Also, the principal consideration to assess the development of a tourism destination is not only the number of tourists visit but also lies instead in its management intervention and the impact of the intervention on the destination's growth. Reflecting on the TALC's limitation, this research also applies the life cycle model analysis by Laurenco because it has better precision in its measurements, with scales represented by intensity level.

The life cycle itself is a graphic tool used to monitor the stages of growth of a region or destination in a long period $[20,26]$. Life cycle analysis lies on a foundation of its empiric longitudinal data of the development process of an area or region. The life cycle analysis emphasizes three factors that will be depicted in a curve diagram or chart based on Holton's quasimodel intensity calculation at each development period or stage. It covers planning, action, and living (impact of the intervention in the form of activity). Those three levels of life cycle analysis have their indicators each. On the planning level, there are indicators such as area strategy, area development guide, planning proposal, area new body, and area framework that will be measured by its intensity. On the action level, the indicators are investment sums, infrastructure building, region's new image, etc. On the living level, the indicators used will refer to two parties; the residents and newcomers or visitors. It covers economic and social opportunities and environment rejuvenation.

The explanation about life cycle analysis above will be the conceptual basis to describe and analyze the development of Ponggok Tourism Village in its function as a tourism destination for a certain period. The latter also serves the objective and focus of this research.

\section{MATERIAL AND METHOD}

Regarding the research objective, to describe the development of Ponggok Tourism Village as a tourism destination, this study is done by the descriptive-qualitative approach. The involving of a descriptive research approach in tourism subject commonly has three reasons: 1) renewing the study on tourism, 2) examining and studying phenomenon changes so it can be described thoroughly, and 3) giving a clear distinction between research and action [27]. However, it needed to be underlined that this study could be categorized as qualitative research due to its hypothesis in the early observations kept developing throughout the research process, along with the data collection and analysis [27].

Meanwhile, life cycle analysis in this study tend to be descriptive-qualitative could be implemented into two steps. The first step is identification and description of existing component conditions, as well as spatial patterns in Ponggok Tourism Village. The second step is identification and description of important events in Ponggok Tourism Village as a tourism destination and its implication to the changes in terms of spatial-space.

Firstly, identification and description of existing component conditions in Ponggok Tourism Village categorized into attractions, amenities, accessibilities, and ancillary services. Meanwhile, the spatial pattern of the tourism destination components could be classified and analyzed with the theoretical foundation [16], which was distinguished into the nucleus, inviolate belt, zone of closure, path, and circulation corridor.

Secondly, as mentioned above, stated the alteration and development of a particular tourism destination cannot happen naturally and free of intervention [20]. Therefore, the use of life cycle analysis to examine and study the 
alterations of a tourism destination emphasizes three factors, i.e. planning, action, and living. These three factors aforementioned will be the premises to identify and describe important events that occurred that were implicating the changes and developments in Ponggok Tourism Village. Below are the variables of this research.

Table 1. Factors of life cycle analysis

\begin{tabular}{ll}
\hline Factors & Description \\
\hline Planning & $\begin{array}{l}\text { Intensity and orientation of planning and } \\
\text { tourism policy }\end{array}$ \\
Action & $\begin{array}{l}\text { Intensity of tourism investation, } \\
\text { development of tourism infrastructure }\end{array}$ \\
Living & $\begin{array}{l}\text { Tourist arrival, revenue, participation of } \\
\text { local community }\end{array}$ \\
\hline
\end{tabular}

Source: Adapted from Alvares \& Laurenço [20] and Butler [28].

Alteration and development of a certain tourism destination were linearly connected to geographic dimension (place and space) [28]. In other words, the use of life cycle analysis in studying the changes and development of a tourism destination must also include its spatial implications. In this research, the life cycle analysis that related to its spatial implication was analyzed from the data of the map categorized according to the period and segments. The former is also classified based on the changing factors reviewed from the time-series changes and development.

\section{Data Collection}

The data obtained from this research were categorized into two classifications, primary and secondary data. The primary data were obtained through observations, mappings, and interviews. The interview was categorized into an in-depth interview with open-ended questions, a structured interview with the closed-ended question, and a Focus Group Discussion (FGD). On the other hand, the secondary data were obtained by two means literary study and institutional survey concerning various documents that connected with the focus of the research. For the data gathering process during the research, there are some tools used, such as a tape recorder, GPS, interview guidelines, ArcGIS 10.2.2, and Avenza Maps.

The research employed a descriptive technique to analyze its data. The data is classified and analyzed according to different stages that each represents: 1) identification and description of the existing component condition of a tourism destination in Ponggok Tourism
Village, as well as its spatial pattern; 2) identification and description of important events occurred in Ponggok Tourism Village as a tourism destination and its implication to changes in terms of spatial-space. The data was then reduced according to the data required. Afterward, the analyzed data presented completely using intelligible sentences based on the result.

Additionally, this study uses the triangulation method to determine the accuracy and validity of the data. This method can be understood as a process to trace the data/information source by examining the evidence from various sources then use it to build a coherent justification according to the study's theme or topic [29]. Refer to various triangulation methods [30], this study used a method (data source triangulation) because it used field observation method, interviews, mapping, FGD, literary study, and then compares it to each other. In other words, this process compares all data obtained from all methods to find correct information.

\section{RESULT AND DISCUSSION}

\section{Ponggok Tourism Village as a Tourism Destination}

According to Regional act, Klaten Regency No. 7 in 2006, about the Guide to Create Organization and Procedures of Village administration, Ponggok has a total area of 77,2255 ha, comprises administratively of four hamlets, i.e. Ponggok hamlet, Kiringan hamlet, Jeblongan hamlet, and Umbulsari hamlet. In orbital, the distance between Ponggok Tourism Village to district capital is $2.5 \mathrm{~km}$ with est. travel time of 5 minutes; to regency capital is $14 \mathrm{Km}$ with an est travel time of 25 minutes; and to the province capital is $90 \mathrm{~km}$ with est. travel time of 120 minutes. Figure 2 is the map of Ponggok tourism village.

The altitude of Ponggok is $225 \mathrm{~m}$ above sea level. So, it is categorized as a plain landscape. Their location is in the watershed, specifically Upstream Bengawan Solo sub-watershed. It is the reason why there are a lot of water springs found in Ponggok. The soil type is gray regosol soil. It is in the tropical climate, with alternately rainy and dry season throughout the year. The average temperature is $28-32.5^{\circ}$ Celcius. The wind speed average is $20-25 \mathrm{~km}$.hour ${ }^{-1}$. The rainfall in 2014-2016 reached 2047-2467 $\mathrm{mm}$.year ${ }^{-1}$ and averaged 179-200 mm.year ${ }^{-1}$. 


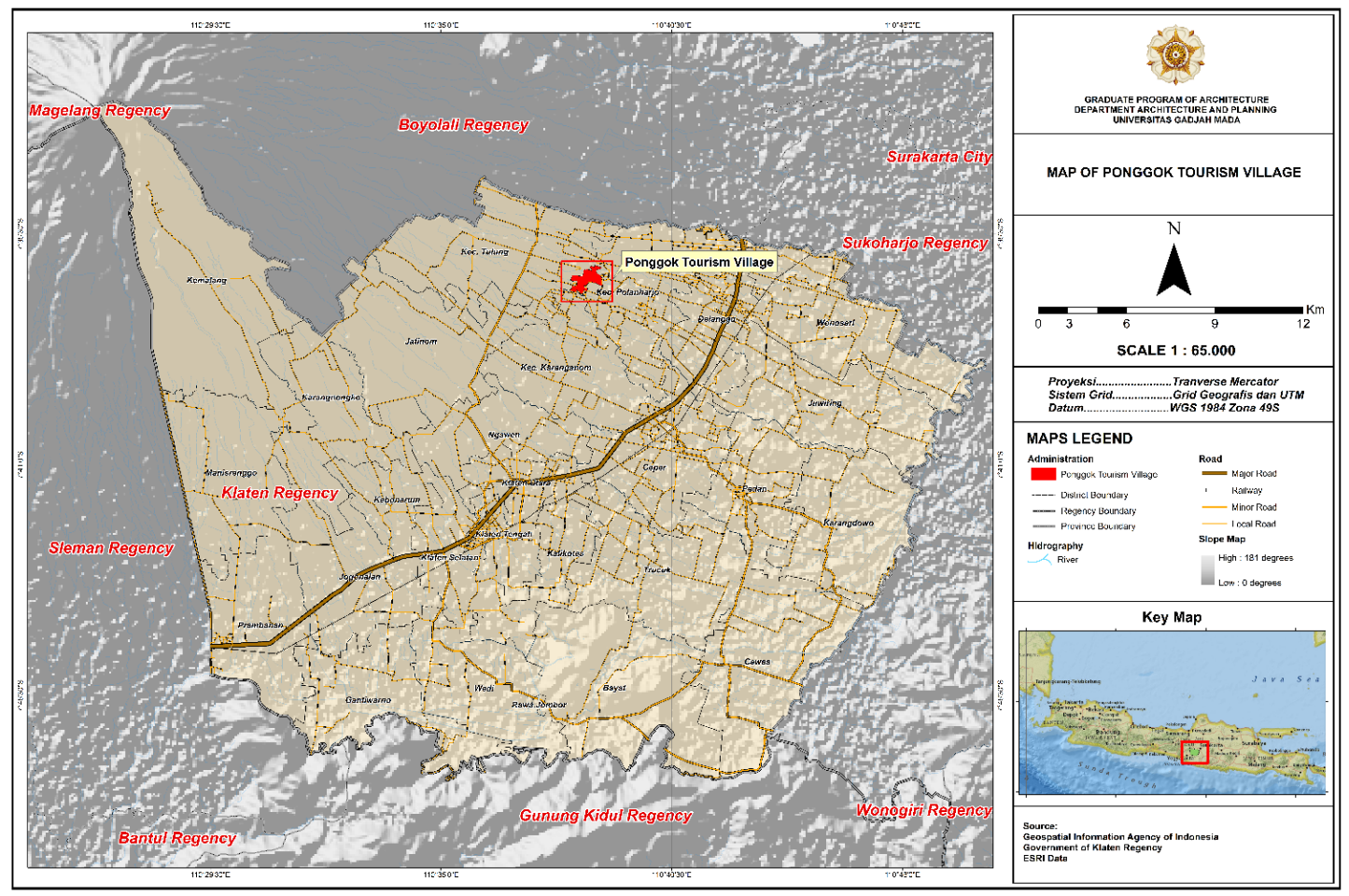

Figure 2. Map of Ponggok Tourism Village

According to the data acquired from the Book of Ponggok Village Profile [31], the land usage of Ponggok is considered as varied. However, the majority of lands were used as irrigated rice fields that cover 55.87 ha or equal to $67.3 \%$ of the total area. The second usage is for the residencies, which cover 12.99 ha or equal to $15.6 \%$. The smallest usage is for Green Space, which existing use is as public cemeteries. It covers 0.2 ha or $0.2 \%$ of the total area.

Ponggok has tourist water-based attractions as its main element. Majority of them are the springs or bathing pools such as Umbul Ponggok, Umbul Besuki, Ponggok Ciblon (Umbul Banyu Mili), and Umbul Sigedang-Kapilaler. Besides that, there are also fishing pools such as Kolam Pemancingan Waduk Galau. The amenities in Ponggok is considered adequate/complete. It has homestays, restaurants, mini markets, TIC, banking facilities (ATM Centre), parking lot, public restroom, signage, and trash bin. Figure 3 is a picture of tourist attractions in Ponggok Tourism Village.

On the tour accessibility, Ponggok Tourism Village can be reached by land transports. The road classes available to access the village from the Regional Activity Center are artery road, local primary road, and neighborhood or village road. All of the roads have been paved with asphalt or concrete. Figure 4 shows the road condition as one of the parts to access the Ponggok Tourism Village.

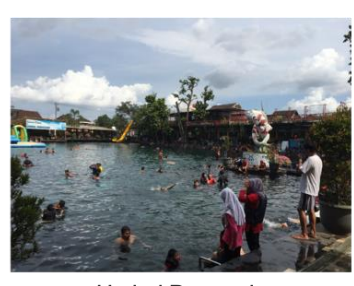

Umbul Ponggok

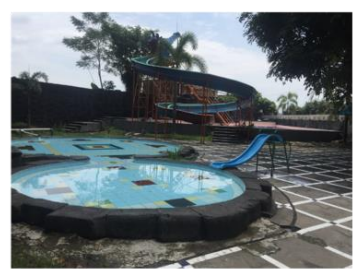

Ponggok Ciblon

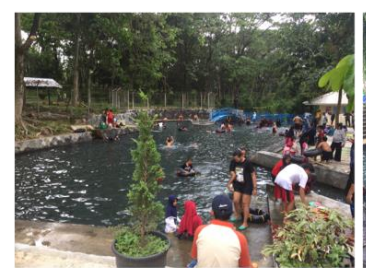

Umbul Sigedang

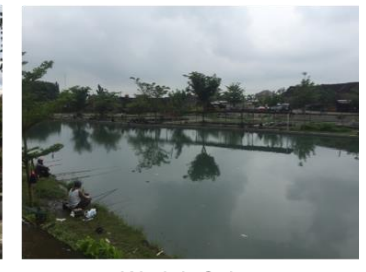

Waduk Galau

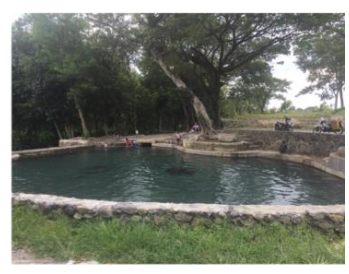

Umbul Besuki

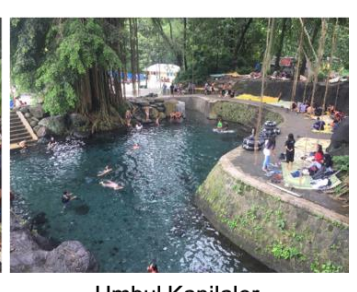

Umbul Kapilaler
Figure 3. Tourist Attractions in Ponggok Tourism Village 

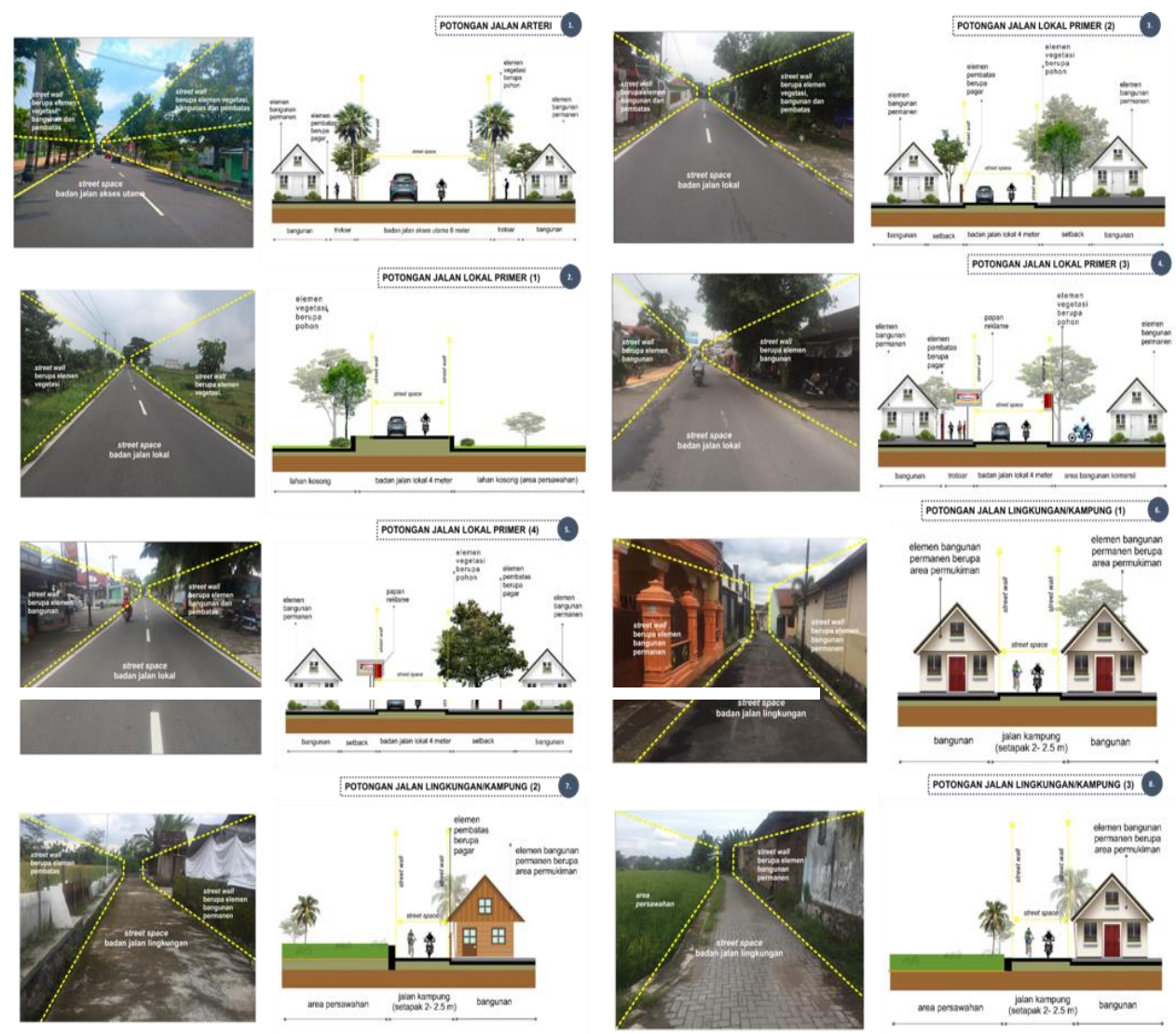

Figure 4. Cutting Segment (Section), accessibility of Ponggok Tourism Village

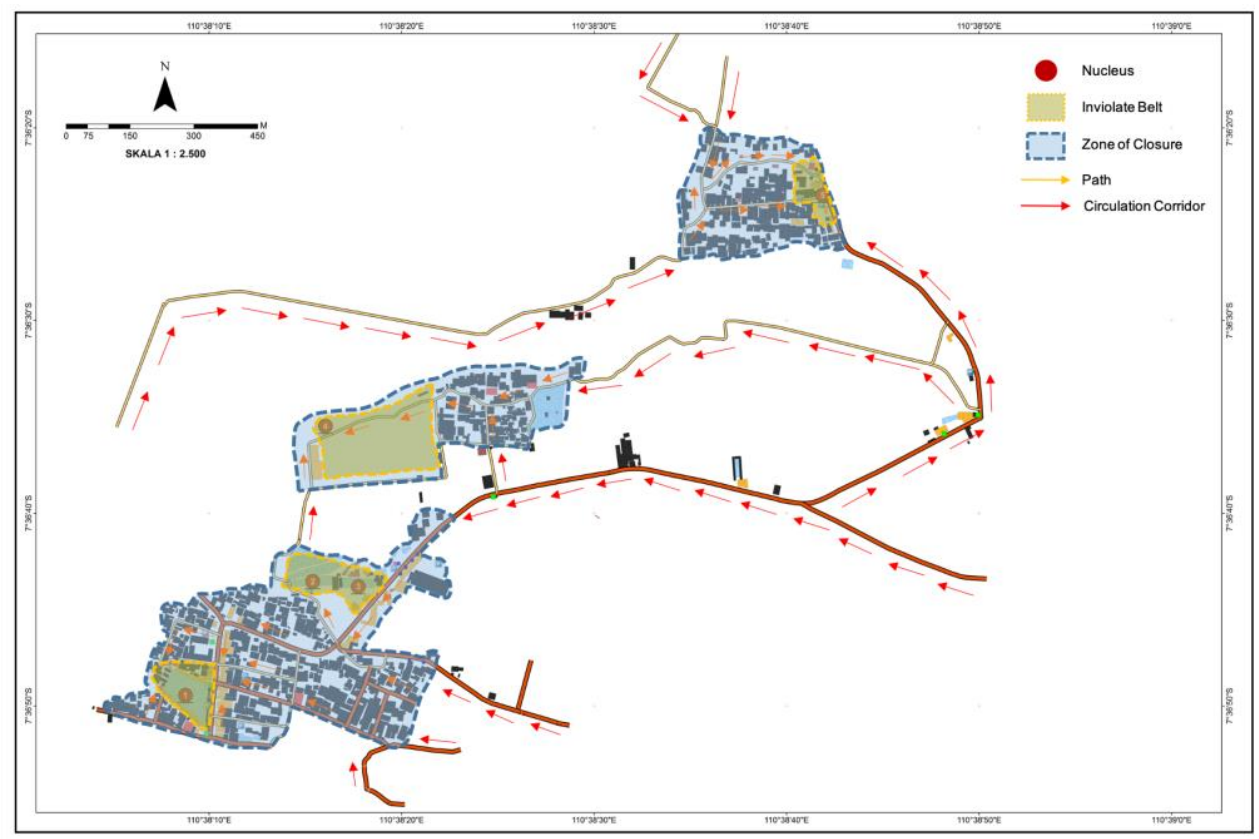

Figure 5. Spatial Pattern of Ponggok Tourism Village Area

On the management sides, Ponggok now relies on two core local organizations, i.e. BUMDes Tirta Mandiri and Pokdarwis Wanuwa Tirta. BUMDes Tirta Mandiri manages Umbul
Ponggok and Ponggok Ciblon while Pokdarwis Wanuwa Tirta is responsible for Kolam Pemancingan Waduk Galau, Umbul SigedangKapilaler, and Umbul Besuki. 
To be specific, in the tourism destination spatial pattern, Ponggok has three zones of closure. They are the zone that covers the area of Dusun Ponggok and Dusun Jeblogan, then zone that covers Dusun Kiringan, and the zone of closure that covers Dusun Umbulsari. From the inviolate belt subject, there are four main zones (Fig. 5). The connectivity between a zone of closure and inviolate belt with the nucleus inside was connected with each and circulation corridor in the form of primary local road and neighborhood or village road.

\section{Time Series Development of Ponggok Tourism Village}

The development of Ponggok from its progression as a tourism destination until the end period of this research can be seen through the longitudinal (diachronic) data that has time series characteristics. Therefore, the basic concept used in this research is leaning toward the life cycle analysis of a tourism destination. This research used Laurenco's model of crossevents life cycle analysis to answer the need. This model emphasizes three big aspects that will be depicted in a curve diagram/chart. Those three aspects affect the development of a tourism area/destination. They will be examined by its intensity according to each aspect of planning, action, and living.

This research used a limited period, specifically, when the Master Plan of Ponggok (RPJMDes) in 2007 was formulated as the first fundamental intervention to develop the tourism activity in Ponggok. Therefore, the time to do the periodic analysis is only limited to the events that happened 12 years before.

Moreover, the planning aspects that occurred and had huge impact on Ponggok Tourism Village as a tourism destination are namely: the disposition of RPJMDes 2007-2013 and the disposition of RPJMDes 2014-2019. On the other hand, the action aspects comprise as follows.

- the construction of infrastructures, such as:

- Gateway

- public sanitation facilities

- $\quad$ irrigation retaining wall

establishment and provision of capital for BUMDes Tirta Mandiri

cooperation with Yogyakarta Diving Center

renovation of Umbul Ponggok

aid fund for:

- UKM (small and medium-sized entreprises)

- $\quad$ PKK (family welfare movement)
- $\quad$ RW (local communities)

- construction of multi-purpose building

- website building and social media accounts for marketing

- construction of fishing pool Waduk Galau

- renovation of Umbul Ponggok area

- reacquisition and renovation of Ponggok Ciblon

- planning arrangement of Umbul SIgedang

- construction of riverside in Umbul SigedangKapilaler area

- Program of community and women empowerment of Ponggok Tourism Village.

esides, living aspects that occurred in Ponggok Tourism Village as a tourism destination between 2011 until 2016, are namely, the implementation of One House for One Bachelor program, settlement of health care insurance premium for underprivileged communities in terms of income from the tourism sector, women empowerment program through PKK by launching locally processed food products such as fishbone steak, and revenue from the tourism sector, reached the total of 3 billion IDR in 2014, 4,7 billion IDR in 2015, 10 billion IDR in 2016, and 12 billion IDR in 2017. The summary of Ponggok Tourism Village development based on planning, action, and living each year since 2007 up to 2018 is drawn in Figure 6.

The summary of Ponggok Tourism Village development can be called as a plan-process behavior. This behavior is depicted in $a \quad b$ dimensional graphic curve, to explains more about the intensity of planning, action, living as explained before. Moreover, this behavior can also be classified with Butler's life cycle analysis. This resulted in a conclusion that the development of Ponggok can be classified in 4 segments of time. The classification of segments of time presented in the curve-graphic (Fig. 7).

a) 2007-2010: exploration and involvement

b) 2011-2013: development

c) 2014-2016: consolidation

d) 2017-2018: stagnation-decline

The development of a tourism area or destination will surely in line with the changes in the spatial-space. It also happened in Ponggok. Each segment has a certain form of spatial-space according to the classification above. This spatialspace transformation can be considered as a consequence of the tourism activities happened there. Figure 8 is the figures for the spatial-space transformation in Ponggok Tourism Village per each time segment. 


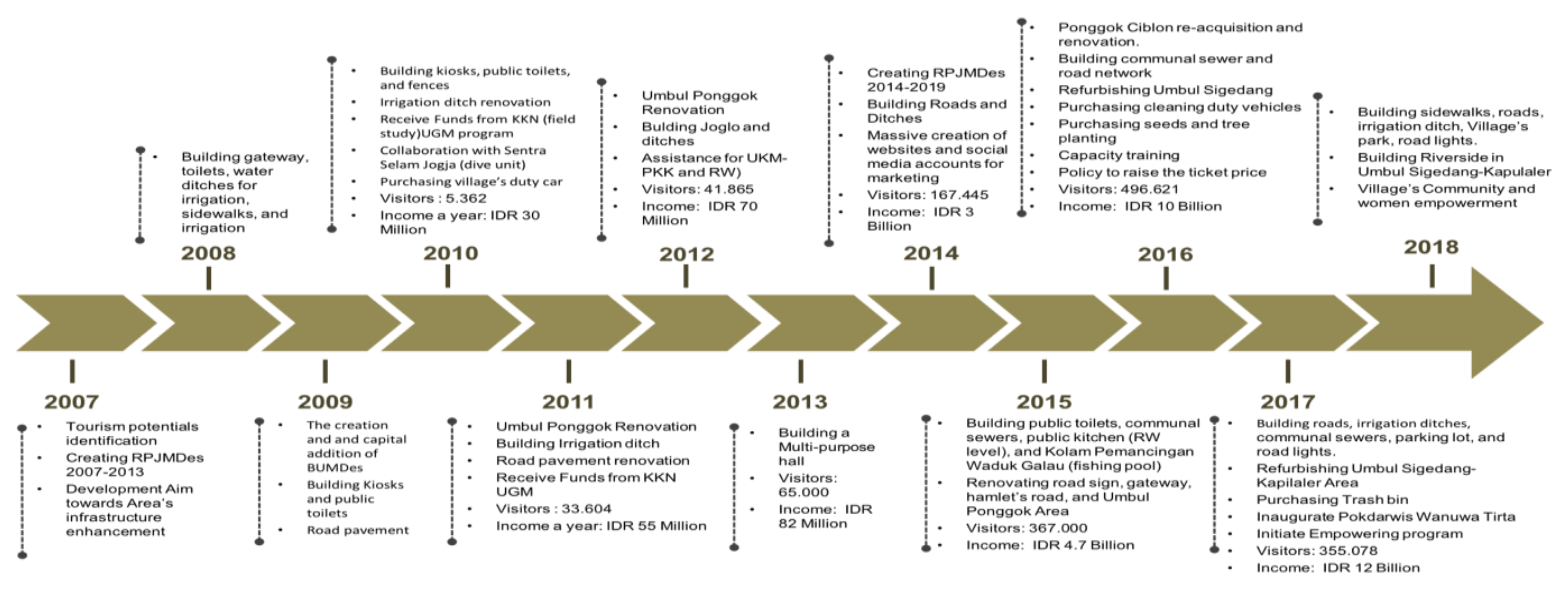

Figure 8. Summary of the time series development in Ponggok Tourism Village

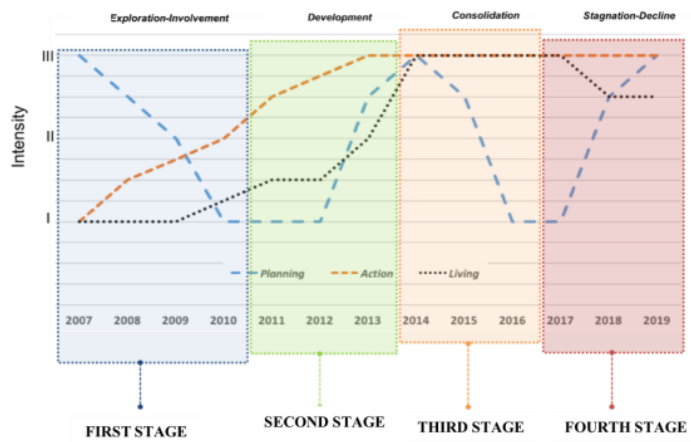

Figure 6. The classification of time segments in the development of Ponggok Tourism Village
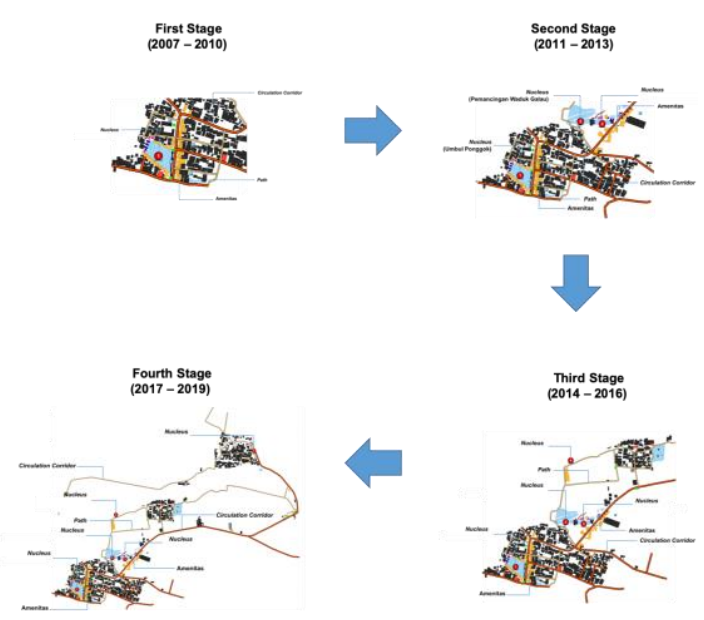

Figure 7. Spatial-space transformation in Ponggok Tourism Village for each segment of time

\section{CONCLUSION}

According to the life cycle analysis, we discovered that the development of Ponggok Tourism Village has four segments of time as reviewed through the intensity of planning, action, and living. The first Exploration and
Involvement happened from 2007 to 2010, the development stage happened from 2011 to 2013, the consolidation stage happened in 2014-2016, the stagnation-decline stage happened in 2017 to 2018. The inter-segment development also implied the changes in the spatial-space of the tourism constellation. From this research, it could be further concluded that Ponggok Tourism Village, as a tourism destination, should make a replanning to avoid the stagnation-decline stage and to stimulate the occurrence of rejuvenation.

\section{ACKNOWLEDGEMENT}

Firstly, we would like to thank Ponggok Tourism Village citizens, particularly the local governance and local communities such as BUMDes Tirta Mandiri and Kelompok Sadar Wisata (Pokdarwis) Wanuwa Tirta, for their hospitality, all data acquired, and their assistance during research processes. Secondly, we also thank the Graduate Program of Architecture, Department of Architecture and Planning, Faculty of Engineering, Universitas Gadjah Mada, for their support during this article/manuscript drafting process.

\section{REFERENCES}

[1]. Spenceley, A. 2008. Responsible tourism: critical issues for conservation and development. Earthscan. United Kingdom.

[2]. Goeldner, C. R. and J. R. B. Ritchie. 2011. Tourism: principles, practices, philosophies, $12^{\text {th }}$ Ed. John Wiley and Sons.

[3]. Sharpley, R. 2015. Tourism: a vehicle for development? In: Sharpley, R. and D. J. Telfer (Eds.), Tourism and Development: Concepts and Issues, $2^{\text {nd }} \mathrm{Ed}$. 3-30. Channel View Publications. United Kingdom. 
[4]. Kausar, D. R. K. 2010. Socio-economic impacts of tourism on a world heritage site: case study of rural Borobudur, Indonesia. PhD Thesis. Graduate School of International Development, Nagoya University. Nagoya.

[5]. Telfer, D. J. 2015. The evolution of tourism and development theory. In: Sharpley, R. and D. J. Telfer (Eds.), Tourism and Development: Concepts and Issues, $2^{\text {nd }} \mathrm{Ed}$. 31-73. Channel View Publications.

[6]. Higgins-Desbiolles, F. 2006. More than an "industry": the forgotten power of tourism as a social force. Tourism Management 27, $1192-1208$.

[7]. Telfer, D. J. and R. Sharpley. 2008. Tourism and development in the developing world. Routledge. London.

[8]. Stronza, A. 2001. Anthropology of tourism: forging new ground for ecotourism and other tourism alternatives. Annual Review of Anthropology 30, $261-283$.

[9]. Jansen-Verbeke, M. and E. Lievois. 2005. Analysing heritage resources for urban tourism in European Cities. In: Pearce, D. and R. W. Butler (Eds.). Contemporary Issues in Tourism Development, 81-106. Routledge. London.

[10]. Leiper, N. 1979. The framework of tourism: towards a definition of tourism, tourist and the tourist industry. Annals of Tourism Research, $390-407$.

[11]. Hall, C. M. 2008. Tourism planning: policies, processes, and relationships, $2^{\text {nd }} \mathrm{Ed}$. Pearson.

[12]. Weaver, D. and L. Lawton. 2014. Tourism management, $5^{\text {th }}$ Ed. John Willey and Sons. Australia.

[13]. Weaver, D. 2006. Sustainable tourism: theory and practice. Elsevier. Oxford.

[14]. Wall, G., and A. Mathieson. 2006. Tourism: change, impacts and opportunities. Blackwell Publishing. London.

[15]. Cooper, C., J. Fletcher, A. Fyall, D. Gilbert, and S. Wanhill. 2005. Tourism: principles and practices $3^{\text {th }}$ Ed. Pearson.

[16]. Gunn, C. A. 2002. Tourism planning: basics, concepts, and cases, $4^{\text {th }}$ Ed. Taylor and Francis.

[17]. Lew, A. A. and B. McKercher. 2006. Modeling tourist movements: a local destination analysis. Annals of Tourism Research 33 (2), 403-423.

[18]. Nuryanti, W. 1993. Concept, perspective and challenges. Paper in the international conference report on cultural tourism, 2-3. Gadjah Mada University Press. Yogyakarta.

[19]. Getz, D., 1992, Tourism Planning and Destination Life Cycle. Annals of Tourism Research 19, 752 - 770.

[20]. Alvares, D.F., and J.M. Laurenço. 2005. Life Cycle Modelling for Tourism Areas. University of Minho. Portugal.

[21]. Hovinen, G. 1981. A tourist cycle in Lancaster County, Pennsylvania. The Cannadian Geographer 15 (3), 283-286.

[22]. Butler, R. 1980. The concept of a tourism area cycle of evolution: implications for management of resources. The Canadian Geographer 24(1), 5-12.

[23]. McKercher, B. 1999. A Chaos Approach to Tourism, Tourism Management 20 (1999), 425-434.

[24]. Hamzah, A., and M.P. Hampton. 2013. Resilience and Non-Linear Change in Island Tourism, Tourism Geographies: An International Journal of Tourism Space, Place, and Environment 15 (1), $43-67$

[25]. Butler, R. 2009. Tourism in The Future: Cycles, Waves or Wheels? Futures 41, 346 352.

[26]. Kusumawanto, A. Z.B. Astuti, and J.M. Laurenço. 2014. Life Cycle Analysis of Jonggol Islamic City in Indonesia, PLURIS 2014 - 60 Congresso Luso-Brasileiro para Planeamento Urbano, Regional, Integrado e Sustentável.-re-inventar-a-cidade-emtempos-de mudança, Portugal.

[27]. Veal, A. J. 2006. Research Methods for Leisure and Tourism: A Practical Guide $\left(3^{\text {rd }}\right.$ Edition). Pearson Education. London.

[28]. Butler, R. 2006. The Concept of a Tourism Area Cycle of Evolution: Implications for Management of Resources. In the Tourism Area Life Cycle: Applications and Modification, Edited by Richard W. Butler, pp. $3-12$. Channel View Publications. Great Britain.

[29]. Creswell, J. W. 2014. Research Design: Qualitative, Quantitative, and Mixed Methods Approaches (4 ${ }^{\text {th }}$ Edition). SAGE Publications.

[30]. Denzin, N.K., and Y.S. Lincoln. 2005. Introduction: The Discipline and Practice of Qualitative Research. In Sage Handbook of Qualitative Research (3 ${ }^{\text {rd }}$ Edition), Edited by Norman K. Denzin and Yvonna S. Lincoln, pp. 1 - 32, SAGE Publications. California.

[31]. Office of Ponggok Village. 2017. Book of Ponggok Village Profile. Ponggok Village. 